\title{
APPLICATION OF RESPONSIBILITY ACCOUNTING TO PRODUCTIVITY EVALUATION IN THE NIGERIAN QUOTED COMPANIES
}

\author{
Dr. Adegbie, Folajimi Festus ${ }^{1 *}$, Dr. Olaoye, A. Samuel ${ }^{2}$ \\ *l (Phd,Mphil, MBA, FCA, FCTI,FCIB) MR.OLUSANJO,OLUGBENGA ROTIMI (Msc,FCA) \\ ${ }^{2}$ (Phd,Msc,Fca) Babcock University, Department Of Accounting, Ilishan
}

\section{*Corresponding Author: -}

\begin{abstract}
: -
The study was designed to identify measure of performance that is related to shareholders wealth and that managers can directly observe and can see the influence of their actions in their responsibilities. The primary objective of business is to maximize the shareholders wealth. The measurement of firm's productivity is a good indicator to assess the realization of this objective. The responsibility to achieve this goal however lies heavily in the hands of managers which has become a major challenge in profit-oriented organizations. It has been observed that responsibility accounting application to evaluate productivity is missing in Nigerian quoted companies, while in some it is not well instituted and administered. The research work adopted an ex-post facto research design, with a focus on the quoted Nigerian quoted companies as at $31^{\text {st }}$ December 2016.A sample size of 53 companies was selected by using a combination of stratified and purposive sampling techniques. Productivity was proxied by earnings per share while Responsibility accounting was proxied by cost of sales, operating cost, net income and Return on Asset. Descriptive and inferential statistics were used for data analyses. The data collected were analyzed using specified regression models with the aid of E-View statistical package. The findings showed that responsibility accounting variables of cost of sales, operating cost, net income and return on assets have positive and significant impact on earnings per share with $p$ values of $t$ statistics $<0.05$. The joint effect of cost of sales, operating cost, net income and return on asset on earning per share is significant. The F-statistics and Adjusted $R^{2}$ values were prob. $F=0.000, R^{2}=0.37$.The Adjusted $R^{2}$ value was not strong in explaining the variations in earning per share. This implied that cost of sales, operating coat, net income and return on asset do not sufficiently explained variations in earning per share. We concluded that responsibility accounting has a significant positive effect on productivity in Nigerian quoted companies. This showed that if all the independent variables can be efficiently managed and controlled, value will be created in the quoted companies. We recommended that managers in profit centres, cost centres and investment centres should focus their actions towards the company's productivity and maximization of the company's value and shareholders wealth.
\end{abstract}

Keywords: Firm value, Shareholder's wealth, Responsibility accounting, Quoted, Productivity, Revenue centre, Cost centre and Investment centre.

\section{(a) $(2)$ (1)}




\subsection{INTRODUCTION}

Investors and potential investors are risk averters who normally want to put their investment in safe havens where there will get maximum returns on their wealth and also experience continuous maximization of the value of the firms. Since the managers take economic decisions that have economic consequences, managers are to act in the best interest of the owners of the business to maintain the principles of entity and going concern. Pandey (2010) posited that since decision-taking authority lies in the hands of managers, their actions should be in the best interest of the owners which will lead to shareholders wealth maximization. Karasioghu and Goktuk (2012) stated the need to delegate management functions, which will lead to decentralization of authorities and enhance motivation, communication, planning and improved productivity. Mohammed, Abdul-rahman, Mahmoud and Atala (2014) had the opinion that somebody must be held responsible for financial transactions otherwise if no one is held responsible, the expenditure on transaction will be out of control. Atu, Ogbeide, Agbo and Clement (2014) see responsibility accounting as profitability accounting or activity accounting where the manager's performance can be evaluated and monitored in an autonomous process. Responsibility accounting can be viewed therefore as a system where the manager is autonomous of other divisions to take decisions on planning, implementation and controlling. Adeniji (2012) opined that responsibility accounting is a system of decentralized authority with performance of division measured in terms of accounting results. Khan(2011) explain that responsibility accounting is an underlying concept of accounting performance measurement systems, which traces costs, revenues, or profits to the individual managers who are primarily responsible for taking decisions.

Pandey (2002) classified manager's responsibility into three distinctive centres for performance evaluation: A cost centre where the manager is solely held responsible for transactional costs within his authority; Profit centre where the where the manager is held responsible for both costs (input) and revenues (output); and the investment centre where the manager is held responsible for the costs, the revenues, the financial operations the investment in assets under his authority. In the responsibility accounting system along with the decentralized structure, Karasioghu andGokturk (2012) opined that "a more democratic system needs to be formed and individuals specialized in management need to have responsibility with regard to expenses, revenues and even investments in the enterprise and in their relevant units within the enterprise; which gives large authority to expert managers regarding the decision-making process to ensure that enterprises operate more effectively and efficiently as well as productively". This means that a manager needs to prepare a responsibility report to evaluate the performance of his/her responsibility centre; which compares the actual results with the budgeted performance in order to measure performance, control activities and implement corrective measures. The essence of responsibility accounting in a structured divisionalized system is to ensure productivity to meet the objective of the organization for firm value maximization and the maximization of the wealth of the shareholders. The survey conducted by American Management Association (1961) on different beliefs and understanding of productivity, $95 \%$ of the respondents viewed that productivity means quality of output as well as quantity while $88 \%$ viewed productivity as the overall efficiency and effectiveness of the operation. Roslas (1948) stated the position of International Labour Organization (ILO) that,a change in productivity of a system results from the combined effects of all the factors contributing to the system's performance. Pandey(2010) posited that shareholders wealth maximization is defined in term of wealth or value of the shareholder equity and this objective can only be achieved when the productivity indicators of the entire organization are fully enhanced and sustained .All these indicators may have positive or negative effect on the productivity of these organizations.

\section{Overview of Nigerian Capital Market Development}

Capital markets are financial markets for primary issues and secondary market trading in long- term investments: equities and bonds. It is a financial market for the trading in long-term securities for funds.According to Central Bank of Nigeria-CBN (2014), Nigeria Stock Exchange(NSE) Board approved a revised corporate strategy on initiatives aimed at sustainability of the market and ensure protection of investors and other stakeholders. The NSE launched the direct market access (DMA) towards the implementation of sponsored access under the West African Capital Markets integration (WACMI) programme. The NSE launched an on- line whistle-blowing portal, the "X-Whistle" to facilitate the submission of tips and referrals regarding violations of the rules, regulations and laws of the Nigerian capital market. CBN indicated bearish sentiments prevailed for most part of the year 2014 as major market indicators trended downwards. Aggregate volume and value of traded securities declined by 59.4 and 43.1 percent respectively, which were attributed to combined effect of several macroeconomic developments and steady divestment from the Nigerian market by foreign investors, following increased currency risk. Aggregate market capitalization as a percentage of the nominal GDP was 15.8 percent in 2014 compared with 23.5 percent in 2013.The primary market segment recorded the first Initial Public Offering (IPO) since the market crash of 2008. At the end of December 2014, the number of listed companies and securities stood at 189 and 253 indicating a decline of 0.50 .4 percent respectively, from the levels in the preceding year.

\subsection{The Research Problem}

The major challenge facing firms is the objectives of the managers running parallel to the corporate objectives of the organization, which make managers not acting in the best interest of shareholders. As the managers are pursuing their own personal goals, the overall economic consequence impact negatively on the performance of the organization. Pandey (2010) opined that the responsibility to maximize the wealth of shareholders lies in the hands of management. Management has the responsibility to report to the owners of the business on the firm value and maximizing the wealth of the shareholders. If the performance of managers is not evaluated, it will be difficult to determine the shareholders 
expectation of wealth maximization and sustainable growth of the organization. There is tendency for wrong evaluation and bias judgment when organization performances are evaluated without recourse to specific responsibility accounting of individual managers. Abysmal performance of managers of many profit organizations especially quoted companies has made it impossible for many organizations to achieve their corporate objectives. Profits dwindle from year to year because of high cost of production which is under the control of the manager. Such costs include raw material cost, direct labour cost, direct expenses and overhead expenses. The uncontrolled costs will have a chain effect on the corporate performance and the market value of the business. The challenge of the volume of activity in relation to every department is very difficult to determine in the absence of responsibility accounting. This results into the challenge of defining asset replacement policy that will enhance productivity. Non-replacement of assets at appropriate time normally leads into low capacity utilization. The consequence is a dwindling asset turnover ratio, which also affects managers inability to create wealth for the shareholders. This also leads to a fall in the market value of the shares negating shareholders expectation capital appreciation and objective of wealth maximization. All these result into poor operational performances from recurring losses, inability to pay dividend, liquidity shortage, inability to meet long term obligations fallen due and litigations from lenders of fund among many. Rayeni and Saljooghi(2012) stated that cost efficiency is the effective choice of inputs vis a vis prices with the objective to attain its profit target and maximize the firm value.Lack of effective responsibility centers has negative impact of this objective.

1.3Objectives of the study: The work was designed to establish the relationship between responsibility accounting and productivity in the Nigerian quoted companiezs. The main research question for this study is know the extent of which responsibility accounting can impact earnings per share, the main proxy for productivity.

1.4. Research Hypotheses: The following hypotheses were set for the research.

H01: There is no significant relationship between cost of sales and earnings per share in the Nigerian quoted companies.

H02: Operating cost has no significant impact on earnings per share in Nigerian quoted companies.

H03: There is no significant impact of net income on productivity on earnings per share in the Nigerian quoted companies.

H04: Return on assets has no significant impact on earnings per share in the Nigerian quoted companies.

Justification and significance of the study: The global meltdown which has affected many nations of the world, Nigeria not exclusive, the exit of some quoted companies especially the

manufacturing(real sector), the phenomenal financial business experienced in the financial industry, not meeting the objectives of the firm and shareholders objectives called for this research. Many investors lost their investments in the wake of financial distress, the crash in the capital market has made has made capital appreciation a dream because of volatility in the market.

The study will benefit the shareholders to assess the performers of managers in the quoted companies. The results of this research will encourage the management of the quoted companies to institute effective responsibility accounting that will focus their objective on firm value maximization and wealth maximization of the shareholders.

\section{Operationalization of Variables}

Independent and dependent variables established for this study is as stated thus: $\mathrm{Y}=\mathrm{f}(\mathrm{X})$

$\mathrm{Y}=$ Productivity (Dependent variable)

$\mathrm{X}=$ Responsibility Accounting (Independent variable) Responsibility Accounting is proxied by:

$\mathrm{x} 1=$ Cost of Sales $(\mathrm{COS})$

$. \mathrm{x} 2=$ Operating Cost $(\mathrm{OC})$

$. x 3=$ Net Income (NI)

.x4=Return on Assets (ROA)

Productivity is proxied by Earnings per share (EPS)

.y1-y4=EPS.

The functional relationship is as follows: $\mathrm{EPS}=\mathrm{f}(\mathrm{COS}) \ldots \ldots \ldots$ equation 1

$\mathrm{EPS}=\mathrm{f}(\mathrm{OC}) \ldots \ldots$...equation 2

$\mathrm{EPS}=\mathrm{f}(\mathrm{NI}) \ldots \ldots \ldots$.....equation 3

$\mathrm{EPS}=\mathrm{f}(\mathrm{ROA}) \ldots \ldots .$. equation 4

$\mathrm{EPS}=\mathrm{f}(\mathrm{COS}, \mathrm{OC}, \mathrm{NI}, \mathrm{ROA}) \ldots .$. equation 5 .

\subsection{Literature Review}

\section{Responsibility accounting and productivity}

Kajola, Adedeji and Olawale (2003) defined responsibility accounting as a system of accounting that segregate revenues and costs into areas of personal responsibility, in order to assess performance attained by persons to whom authority has been assigned. Mojgan (2012) explained that responsibility accounting that reports managers' areas of responsibility relating to cost, and revenue. Pandey (2002) gave the following principles underlying responsibility accounting: a clear definition of responsibility centre within an environment of business, where for each centre, the extent of the responsibility is made known. The controllable and non-controllable financial activities are specified,with specified accounting system to accrue information for the responsibility centre. Performance reports are therefore 
prepared for the intending users. Adeniji (2012),Kajola et al(2003) and Nedles, Powers and Crosson (2002) identied three centres for responsibility evaluation: cost centre is a responsibility centre where the manager is assessed for the controllable costs under his/her signing authority; profit centrre where the manager effective is assessed for both cost and revenue in their monetary terms; investment centre is a responsibility centre where that manager is assessed for profit generation, the financing of the business and cost. Here measures like return on investment, residual income, and economic added valued are used for the performance evaluation; and revenue centre where the manager is accountable primarily for revenue, and whose success is based on revenue against the budgeted figures.

The concept of productivity is very important in the evaluation of quoted companies; as the results of the evaluation will have the market value of the firm, the shareholders expectation on wealth maximization.

Mojgan (2012) in study viewed performance management is to evaluate the economic planning and outcome of various responsibilities to include return on investment (ROI), residual income (RI),return on sales( ROS), economic value added (EVA),market value added (MVA). He explained that EVA is the profit of the business unit after deducting tax charge and cost of capital.The EVA focuses on shareholders because by deducting and deducting expected return, EVA reflects economic profitability, which make behave that they are owners of the firm. He asserted further that market value added (MVA) measures the external performance by comparing the average market value of shareholders' equity with the book and value of the equity. Positive changes every year to have a correct analysis of the performance. Fowzia(2011) examined responsibility accounting and the measure of satisfaction levels of service organizations in Bangladesh. Using explanatory survey research design and analysis of variance to test the data,he found out that organizations use more than one responsibility centre like cost centre,revenue centre, profit centre, profit centre and contribution centre, and that the most frequently used is the profit centre, followed by revenue and investment centre. Cost centre is third in ranking while contribution is the least common. The result revealed that three factors of satisfaction levels of assignment of responsibility, performance measurement and performance measurement benchmark have significant at 0.05 level of significance, have significant influence on overall satisfaction level of responsibility accounting system.

Ikon and Nwankwo (2015) examined production planning and profitability of selected manufacturing firms in Nigeria. With the use of Ordinary Least Square and time series analysis, their result showed that turnover has a positive and significant relationship with profitability and $\log$ of production cost has a negative but statistically significant relationship with profitability. Oyerogba, Olaleye and Solomon (2014) investigated the relationship that exists between cost management practices and firm's performance in 40 manufacturing organizations listed on the Nigeria Stock Exchange Secondary data extracted from audited financial statements were analyzed. Direct material cost, direct labour cost, production overhead cost and administrative overhead cost were analyzed against profitability of the sampled population. The results indicated a significant positive relationship between direct material cost, direct labour cost and firm performance. However, production overhead cost and administrative overhead cost were found to be negatively correlated with firm performance. They recommended that a cost reduction strategy with emphasis on production overhead cost and administrative overhead cost should be embarked upon if their profit maximization and wealth creation objective must be achieved.Oyadonghan and Ramond (2014) studied the effect of quality cost management on firm's profitability in Bayelsa State.The result of the analysis showed that there is a significant relationship between quality cost management and firm profitability.

Effiok and Blessing (2015) examined cost information and business strategy as a synergistic approach of ensuring valid business decision and growth in Nigerian quoted companies. They used ex-post facto and descriptive research designs were adopted to elicit information from respondents. The findings revealed a positively significant relationship between cost information and business performance a positively significant relationship between business strategy and corporate governance and business performance. Kabajeh,Al Nu'aimat and Dahmash (2012) studied the relationship between the return on assets, return on equity, and return on investment ratios together and separately with Jordanian insurance public companies share prices for a five period of 2002 to 2007.They obtained the following results: the pooled analysis of the ROA,ROE, and ROI combined showed a strong and positive relationship with share prices and a strong explanatory power. The linear relationship showed a positive but low relationship between each of ROA and ROI ratios with market share prices of Jordanian insurance public companies. The linear relationship between the ROE ratio with market share prices of Jordanian insurance public companies showed no relationship. Gharaiba, Debi and Abo (2011) examined the extent of implementing responsibility accounting features in Jordanian industrial corporations and its effect on profitability and operational efficiency aimed at exploring the extent to which responsibility accounting features are implemented impact profitability and operational efficiency. Their results showed that there is a significant relationship implementing responsibility accounting features and the company's profitability and operational efficiency. Muneer,Faroug,Mohammed and Ata (2016) opined for the need of a manager to use responsibility in view of the rarity of resources and industrial competition. The study was empirical and adopted survey research design. The result showed that companies give premium to responsibility accounting by determining the position of responsibility centers and capable managers to manage them. That static model of performance required the implementation of responsibility accounting. The report showed that industry gives much importance to cost analysis. Andor (2014) opined that globalization has intensified market competition which calls for management strategy to survive and sustain business. That in this situation, managers need critical analysis of relevant cost and performance information. The paper was theoretical, and concluded that an organization needs decentralization into revenue, cost, profit and investment centers, which will allow individual managers to manage the key elements in their segments.

Maran, Bracci,and Inglis (2018) opined that institutional context created pressure on public sector organization to implement performance management systems of balance scorecards. 
Based on structuration theory, they concluded that the re-interpretation of human institutional, economic factors, the inclusion of historic and culturally specific perspective are necessary in order to achieve sustainable performance. Meo, Lara and Surroca (2017) asserted that against the agency theorists believe managerial entrenchment provides benefits to the equity holders and helps managers to be less narrow-minded in earnings management in order to achieve their set short- term goals. They averred that when managers enjoy incentives to manipulate firms' performance, the entrenched managers are less prone to activities that will have negative effects on shareholders. Joshi (2016) asserted that businesses must demonstrate efforts to incorporate externally effects in decision making as a prerequisite for obtaining legitimacy and license to operate that sustainability accounting will help firms to meet the information needs of external stakeholders and facilitate strategically material internal decisions by managers.

\section{Assets and productivity}

Warrad and Omari (2015) examined the impact of turnover ratios on Jordanian service sectors' performance between 2009 and 2012. Their results showed that there is no significant impact of total asset turnover ratio (ATR) on the return on Assets(ROA) of Jordanian services sectors ,no significant impact of total asset turnover ratio (ATR) on return on equity(ROE) .Beinabaj, Soleiman and Rashidi (2013) studied the relationship between total asset turnover and productivity indicators of companies listed in Tehran Stock Exchange using multiple regression analysis to investigate the impact of employee productivity, capital productivity and total-factor productivity on total asset turnover. The result showed that there is a significant relationship between total assets turnover ratio and capital productivity and total-factor productivity indicators. Sayeed and Hogue (2009) studied the impact of assets and liability management on profitability of public and private commercial banks in Bangladesh. According to them, banks' profitability is almost always of concern in modern economy and that profitability of banks is directly affected by management of their assets and liability. The results showed that all of the assets have significant contribution to total income of the private banks. Okwo (2012) examined the investment on fixed assets on firm profitability, evidenced from the Nigerian Brewery Industry.A cross sectional data was gathered for the analysis from the annual reports of sampled brewery firms for a period of 1995 to 2009. With the adoption of multiple linear regression analysis method,the result showed that the level of investment in fixed assets did not have strong and significant effect on the level of reported profit of breweries in Nigeria.Khalid (2012) examined the relationship between the asset quality management proxies and profitability nexus.Using the return on assets and profitability ratios for the period 2006 to 2011, the multiple regression model employed showed a result that bad asset ratio are negatively associated with banking operating performance.Enekwe (2015) examined the relationship between financial ratio analysis and corporate profitability of selected quoted oil and gas companies in Nigeriam. Total assets turnover ratio (TATR), debt equity ratio (DER), debtor's turnover ratio (DTR), interest coverage (IC) and creditors turnover ratio (CTR) were employed to determine their relationship and effect on corporate profitability (Return on assets) of oil and gas companies in Nigeria. He used ex-post facto research design for the work. He employed descriptive statistics, pearson correlation and regressions to find out their relationships. The results of the analysis showed that total asset turnover has a positive relationship and statistically significant with corporate profitability, while others were statistically insignificant with corporate profitability.

\section{Cost Management and Efficiency}

Cost efficiency is defined as the effective choice of inputs vis avis prices with the objective to minimize production costs, while technical efficiency investigates how well the production process converts inputs into outputs (Rayeni and Saljooghi, 2012).Robert (2007) as cited in Oyerogba, Olaleye and Solomon (2014) stated that a company with adequate cost structure possesses the higher chance of attaining its profit target. Further that for adequate profit to be recorded from a business there is a need for adequate control of cost. Inner, John, Mitchell and Sinclair (2000) assert that the survival triplet today for any company is how to manage productive cost, quality, and performance. That customers are continuously demanding high quality and better performance products or services and at the same time, they want the price to be reasonably low. The shareholders are also demanding a required rate of return on their investment from the company. That cost has become a residual and the challenge is being able to manufacture products or provide services within the acceptable cost framework. Nedles, Powers and Crosson (2002) asserted that a responsibility centre whose manager is accountable only for controllable costs that have well-defined relationships between the centre's resources and products or services.

Yeshmin and Fowzia (2010) asserted that management accounting is a financial technique for the effective and efficient performance evaluation of a manager. That is for a manager to achieve set goals,he/she must develop strategic plans, and try to evaluate performance for useful decision taking. They explained further that business environment has become more automated for cost determination, while managers are held responsible for cost ascertained under his responsibility. The researcher employed survey method of design with the administration of questionnaire to the respondents in the manufacturing and service industry. The findings showed that each manager applied management accounting technique to achieve performance in their responsibilities.

\subsection{Theoretical Framework}

The following theories are closed related to this research work:

221 Agency theory: This theory was developed by Berle and Means (1932) which concerns the relationship between the principal (shareholders) and the agent of the principal(company's managers).An agency relationship arises whenever one or more individual, called principals, hire one or more other individuals, called agents, to perform some 
services and then delegate decisions-making authority to the agents. Berle and Means (1932) argued that due to a continuous dilution of equity ownership of large corporations, ownership and control become separated into a fullfledged agency problem which is comprise within the economic theory of the firm, where costs of agency problem has been identified and who bears the costs. This situation gives professional managers an opportunity to pursue their interest instead of that of shareholders as stipulated by Jensen and Runback (1983).In this theory, the shareholders are the owners of the company and the task of the company's directors is to ensure that shareholders' interests are protected and maximized. Elliot and Elliot (2002) stated that the duty of directors is to run the company in a way which maximizes the long term return to the shareholders, and thus maximizes the company's profit and cash flow. The challenge in most organizations is that the interests of the principal and the agent are never exactly the same, thus, the agent who is the decision-making part tend to always pursue his own interests more that of the principal. The main challenge faced by the shareholders is to ensure that managers will return excess cash flow to them through dividends payouts. Jensen and Meckling (1976) defined agency costs as summation of the monitoring costs, bonding costs and residual loss. The owners limit the abnormal activities of the managers, by incurring monitoring costs. They establish appropriate incentives such as management compensation policies to ensure that the managers behavior align with the owners interest. In agency theory the agent should operate within the corporate objectives, align his personal objectives with corporate objectives to ensure the maximization of the value of the firm. The agent will ensure disclosure of adequate information to put the principal in a comfortable situation.

222 Stakeholder theory: Pandel (2010) asserted that stakeholder theory is based on the premise that the fundamental responsibility of managers is to maximize the total wealth of all stakeholders of the firm, rather than only the shareholders' wealth. In this situation, corporate governance efforts are intended to empower those stakeholders who contribute or control critical resources and skills, to ensure that the interests of these stakeholders are aligned with that of the shareholders. Freeman (1984) propagated the theory by incorporating them into categories of business planning and policy model, and a corporate social responsibility model of stakeholder management. The first model analysis focuses on developing and evaluating the approval of corporate strategies decision by groups whose support is required for the firm's continued existence. The stakeholders identified include the owners, customers, public groups ans suppliers. The second model states that the corporate planning and analysis extends to include external influences which may be adversarial to the firm. These adversarial groups may include the regulatory environmentalist and or special interest groups concerned with social issues. This model enables managers and accountants to consider a strategic plan that is acceptable to change in the social demands for non-traditional stakeholders groups.

223 : Signaling theory: Ross(1977) developed an incentive signaling model, which provides for the determination of the financial structure of the firm. It is assumed in this model that the manager possesses inside information about the activities of the firm and thus is precluded from trading in his own instruments. In a competitive equilibrium, financial choices will be made by the manager if the investors know the manager's incentive scheme to determine the firm's worth.

\section{4 : Economic Efficiency Theory}

Economic efficiency theory states that companies should achieve their output at the lowest possible cost per unit produced. According to this theory, optimal production can be achieved by economies of scale. Thus, in the short run, maximum operational efficiency is attained at the level of output at which all accessible economies of scale are taking advantage of such efficiency. In the long run, lifting the capacity of existing systems can increase the optimal level of productive efficiency (Zerbe, 2001; Said, 2011). There are two perspectives of economic efficiency theory; allocative (price) efficiency criteria that states that for companies to operate at efficient level, then all companies products have to be priced optimally. The productive efficiency (technical efficiency) takes place when the business employs all of its resources efficiently, producing the most output from the least input as concluded by Said(2011).

The first two models see the agents as having primary responsibilities to operate the organizations as separate entities that must report the consequences of their economic decisions to the owners and stakeholders. They need to operate responsibility accounting system in order to prepare stewardship accounting for assessing the satisfaction of the objectives of the shareholders, the stakeholders and the firm. The signaling theory gives the manager the power to determine the financial structure of the firm to gain the firm value, which can be done through responsibility accounting system. The work is connected to economic efficiency theory as all responsibility centers have common objective of maximum output with the full utilization of available resources. 


\section{Conceptual Model}

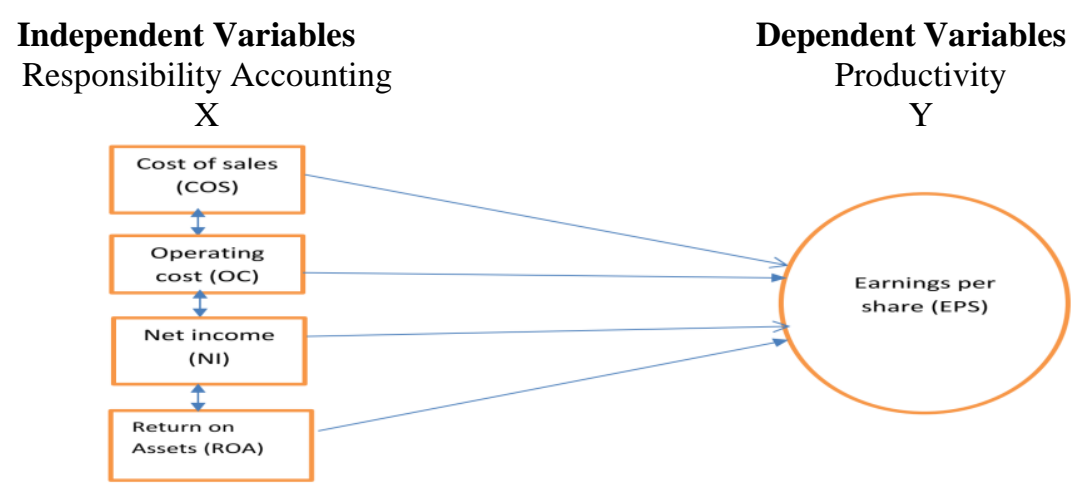

Figure 2.1.1 Expected Model

Source: Researcher's model (2017)

The model 2.1.1 explains that all the independent variables of COS, OC, NI,and ROA with linear relationship will influence the dependent variable of earnings per share.

3: Methodology: This study was designed to assess the application of responsibility accounting to productivity evaluation in the Nigerian quoted companies from year 2011 to 2015.The study adopted ex post facto research design, which allows the investigation of transactions after the fact has occurred without interference from the researcher. The population for the comprised all quoted companies in the Nigerian Stock Exchange.as $31^{\text {st }}$ December 2015.which was put at 183.The companies were stratified according to the industries, and we used probability scientific sampling technique of finite population developed by United States National Education Commission to obtain a sample size of 53 companies from the population. Secondary data used were sourced from published annual reports and accounts of the companies, and Nigeria Stock Exchange Fact book. Responsibility accounting performance indices were proxied by cost of sales, operating cost, net income and return on assets while productivity was proxied by earnings per share for a period of 5years a total of 265 company year and 1,325 observations. The validity of the extracted data was based on the crosschecking of the accuracy and correctness of figures by the reserachers. The reliability was based on the fact that the accounts of the companies were statutorily audited by independent auditors and accounts approved for use the regulatory authorities (Manufacturing Association of Nigeria and Nigerian Stock Exchange).

3.1. Method of data analysis: The study employed descriptive and inferential statistics to analyze the data collected from annual reports and accounts of the sampled companies. Linear regression was used to analyze the relationship between independent variables and the dependent variable, while multiple regression was used to determine the combined effect of the independent variables on the dependent variable in each of the hypotheses.

\subsection{Model specification:}

Functional Form: $\mathrm{EPS}=\mathrm{f}($ cost of sales, operating cost, Net income and Return on Assets) Econometric Form:

$\mathrm{EPS}=\beta 0+\beta 1 \log \mathrm{COS}_{\mathrm{it}}+\beta 2 \log \mathrm{OC}$ it $+\beta 3 \log \mathrm{NI} i \mathrm{t}+\beta 4 \log \mathrm{ROA}$ it $+\mathrm{e}$

Linear Regression Model:

EPS $_{i t}=\beta 0+\beta 1 \log \operatorname{COS}_{\text {it }}+\mathrm{e} \ldots \ldots \ldots \ldots$....... 1

EPSit $=\beta 0+\beta 2 \log O C_{i t}+$ e..............Model 2

EPSit $=\beta 0+\beta 3 \log \mathrm{NI}_{i t}+\mathrm{e} \ldots \ldots \ldots \ldots \ldots$........ 3

EPSit $=\beta 0+\beta 4 \log$ ROAit + e.................Model 4

Multiple Regression Model

EPSit $=\beta 0+\beta 1 \log C O S i t+\beta 2 \log O C$ it $+\beta 3 \log N I_{i t}+\beta 4 \log R O A i t+e \ldots \ldots$. Model 5

A Priori expectation is that $\beta 1, \beta 2, \beta 3$, and $\beta 4>0$

\subsection{Decision rule:}

The specified models were tested on $95 \%$ confidence, which is $5 \%$ level of significance. Student's tdistribution for linear regression:

If Prob $\geq 0.05$ accept $\mathrm{H} 0$ and reject $\mathrm{H} 1$ If

Prob $\leq 0.05$ accept $\mathrm{H} 1$ and reject $\mathrm{H} 0$

F-distribution for joint effect of all variables-multiple regression

If Prob. $\geq 0.05$ accept $\mathrm{H}_{0}$ and reject $\mathrm{H}_{1}$ If

Prob. $\leq 0.05$ reject $\mathrm{H} 0$ and accept $\mathrm{H} 1$ 
4. Data analyses, results and discussion of findings Table 4.1.

Descriptive statistics

\begin{tabular}{|c|c|c|c|c|c|}
\hline & LOGCOS & LOGOC & LOGNI & ROA & EPS \\
\hline Mean & 16.63325 & 13.42751 & 13.13627 & 0.071745 & 254.9885 \\
\hline Median & 16.75286 & 13.53945 & 14.06892 & 0.048931 & 123.4223 \\
\hline Maximum & 19.48806 & 18.65152 & 19.11980 & 0.471225 & 997.0000 \\
\hline Minimum & 11.87180 & 9.104758 & 0.000000 & 0.000000 & 0.000000 \\
\hline Std. Dev. & 1.759400 & 2.006489 & 4.403317 & 0.075050 & 293.8847 \\
\hline Skewness & -0.296612 & 0.145177 & -2.042705 & 1.775139 & 1.232021 \\
\hline Kurtosis & 2.155813 & 2.713808 & 6.817848 & 7.056884 & 3.152449 \\
\hline Jarque-Bera & 11.75459 & 1.835247 & 345.2347 & 320.9015 & 67.29615 \\
\hline Probability & 1.02802 & 1.399467 & 0.725489 & 1.147859. & 0.082594 \\
\hline Sum & 4407.812 & 3558.290 & 3481.113 & 19.01248 & 67571.95 \\
\hline $\begin{array}{ll}\text { Sum } & \text { Sq. } \\
\text { Dev. } & \\
\end{array}$ & 817.2087 & 1062.863 & 5118.750 & 1.486979 & 22801211 \\
\hline Observations & 265 & 265 & 265 & 265 & 265 \\
\hline
\end{tabular}

Source: Researcher's computation 2017

From the Table there are no much statistical differences in the minimum, maximum, mean and standard deviation scores. Earnings per share (EPS) has a maximum of about 997 and an average of 254.9 while the minimum for the period covered is 0 . The minimum cost of sales (LOGCOS) for the period studied is about 11.87, the maximum is about 19.48 while the average amount for the period studied is about 16.63. The minimum operating cost (LOGOC) for the period studied is about 9.10 , the maximum is about 18.65 while the average amount for the period studied is 13.43 . The minimum net income (LOGNI) for the period studied is 0 , the maximum is about 19.12 while the average amount for the period studied is about 13.14. The minimum return on asset (ROA) for the period studied is 0 , the maximum is about 0.47 while the average amount for the period studied is about 0.07 . The standard deviation shows the dispersion or spread in the data series. The higher the value of standard deviation, the higher the deviation of the series from its mean and, the lower the value of standard deviation, the lower the deviation of the series from the mean. The highest standard deviation value is EPS 293.8 and the minimum standard deviation is ROA with a value of 0.08. Skewness measures the asymmetry of the distribution of the series around its mean. For the sampled companies in this study, the variables EPS, LOGOC, and ROA are positively skewed while LOGCOS and LOGNI are negatively skewed. A distribution is said to be positively skewed when it has 'a long tail to the right' meaning most values are concentrated on the left of the mean with extreme values to the right.Kurtosis measures the peakedness or flatness of the distribution of the series. From the above table all the variables are peaked (leptokurtic) in relation to the normal distribution.The Jarque-Bera is a test for normal distribution. All the probability values for the Jarque-Bera test are greater than $5 \%$ (0.05), hence it confirms a normal frequency distribution.

\section{Test of Hypothesis One (H01)-}

$\mathrm{H} 0=$ There is no significant relationship between cost of sales and productivity in Nigerian quoted companies.

Cross-sections included: 53

Total panel (balanced) observations: 265

\begin{tabular}{lcccc}
\hline Variable & Coefficient & Std. Error & t-Statistic & Prob. \\
\hline \hline C & -1083.208 & 150.9745 & -7.174773 & 0.0000 \\
LOGCOS & 80.45307 & 9.026500 & 8.912986 & 0.0000 \\
\hline \hline R-squared & 0.231985 & Mean dependent var & 254.9885 \\
Adjusted R-squared & 0.229065 & S.D. dependent var & 293.8847 \\
S.E. of regression & 258.0393 & Akaike info criterion & 13.95162 \\
Sum squared resid & 17511668 & Schwarz criterion & 13.97864 \\
Log likelihood & -1846.590 & Hannan-Quinn criter. & 13.96247 \\
F-statistic & 79.44132 & Durbin-Watson stat & 2.345321 \\
Prob(F-statistic) & 0.000000 & & \\
\hline \hline
\end{tabular}

Source: E-Views Regression analysis results 
EPSit $=\beta 0+\beta 1 \log C O S i t+e i t$

EPSit $=-1083.2+80.453 \mathrm{COS}$

The result of the regression estimate for model 1 indicates that cost of sales has positive effect on productivity. This is indicated by the sign of coefficient $(\beta 1=80.453)>0$. Thus, cost of sales is consistent with pre-estimation expectations.The R-squared showed that about $23 \%$ variations in EPS can be attributed to cost of sales and the remaining $77 \%$ variations in EPS for the sampled companies were caused by some other factors not included in this model.The probability of $\mathrm{t}$ - statistics showed $0.0 \%$ for the sampled companies. This shows that the regression result is statistically significant because this is lower than $5 \%$, which is the level of significance adopted for this study. i.e 0.000 $<0.05$. The coefficient showed that one unit change in cost of sales will cause a positive 80.45 unit change in EPS. This positive effect of cost of sales on EPS is significant in this study.From the above regression estimates, cost of sales has a significant positive effect on EPS. Therefore, from the test of hypothesis one, the null hypothesis is rejected while the alternative hypothesis is accepted, research question one is answered and research objective one is achieved. This shows that there is a significant relationship between cost of sales and EPS in Nigerian quoted companies.

\section{Test of Hypothesis Two (H02)}

H0=There is no significant effect of operating cost on productivity in Nigerian quoted companies.

Cross-sections included: 53

Total panel (balanced) observations: 265

Table 4.3 Regression table Operating cost.

\begin{tabular}{lclll}
\hline \hline \multicolumn{1}{c}{ Variable } & Coefficient & Std. Error & \multicolumn{2}{c}{ t-Statistic Prob. } \\
\hline \hline C & -478.4773 & 113.7666 & -4.205778 & 0.0000 \\
& 54.62411 & 8.379959 & 6.518422 & 0.0000 \\
\hline \hline R-squared & 0.139088 & Mean dependent var & 254.9885 \\
Adjusted R-squared & 0.135814 & S.D. dependent var & 293.8847 \\
S.E. of regression & 273.1999 & Akaike info criterion & 14.06580 \\
Sum squared resid & 19629847 & Schwarz criterion & 14.09282 \\
Log likelihood & -1861.719 & Hannan-Quinn criter. & 14.07666 \\
F-statistic & 42.48982 & Durbin-Watson stat & 2.298937 \\
Prob(F-statistic) & 0.000000 & & & \\
\hline \hline
\end{tabular}

Source: E-View Regression analysis result

$\mathrm{EPS}=\beta 0+\beta 1 \log \mathrm{OC}$ it+eit

EPS $=-478.47+54.6240 \mathrm{OC}$

The result of the regression estimate for model 2 indicates that operating cost has positive effect on EPS. This is indicated by the sign of coefficient $(\beta 1=54.624)>0$. Thus, operating cost is consistent with pre-estimation expectations. The R-squared showed that about $14 \%$ variations in EPS can be attributed to operating cost and the remaining $86 \%$ variations in EPS for the sampled companies were caused by other factors extraneous to this study. The probability of t-statistics showed $0.0 \%$ for the sampled companies. This shows that the regression result is statistically significant because this is lower than $5 \%$, which is the level of significance adopted for this study i.e $(0.000<0.05)$. The coefficient showed that one unit change in cost will cause a positive 54.62 unit change in EPS. This positive effect of operating cost on EPS is significant in this study.From the above regression estimates, operating cost has significant effect on EPS. Therefore, from the test of hypothesis two, the null hypothesis is rejected; research question two is answered and research objective two is achieved. This shows that there is a significant effect of operating cost on EPS in Nigerian quoted companies.

\section{Test of Hypothesis Three (H03)}

$\mathbf{H 0}=$ There is no significant relationship between net income and productivity in Nigerian quoted companies.

Cross-sections included: 53

Total panel (balanced) observations: 265 
Table 4.4 Regression on Net Income

\begin{tabular}{lrlll}
\hline \hline \multicolumn{1}{c}{ Variable } & Coefficient & Std. Error & t-Statistic & Prob. \\
\hline \multicolumn{1}{c}{ C } & -30.60774 & 53.89803 & -0.567882 & 0.5706 \\
\multicolumn{1}{c}{ LOGNI } & 21.74104 & 3.890994 & 5.587527 & 0.0000 \\
\hline \hline R-squared & 0.106112 & Mean dependent var & 254.9885 \\
Adjusted R-squared & 0.102714 & S.D. dependent var & 293.8847 \\
S.E. of regression & 278.3829 & Akaike info criterion & 14.10339 \\
Sum squared resid & 20381718 & Schwarz criterion & 14.13041 \\
Log likelihood & -1866.699 & Hannan-Quinn criter. & 14.11425 \\
F-statistic & 31.22046 & Durbin-Watson stat & 2.428236 \\
Prob(F-statistic) & 0.000000 & & & \\
& & & & \\
\hline
\end{tabular}

Source: E-View Regression analysis results

$\mathrm{EPS}=\beta 0+\beta 1 \log \mathrm{NI}_{\mathrm{it}}+\mathrm{e}_{\mathrm{it}}$

$\mathrm{EPS}=-30.6+21.741 \mathrm{NI}$

The result of the regression estimate for model 3 indicates that net income has positive effect on EPS. This is indicated by the sign of coefficient $(\beta 1=21.741)>0$. Thus, net income is consistent with pre-estimation expectations. The Rsquared showed that about $11 \%$ variations in EPS can be attributed to net income and the remaining $89 \%$ variations in EPS for the sampled companies were caused by other factors extraneous to this study. The probability of t-statistics showed $0 \%$ for the sampled companies. This shows that the regression result is statistically significant because this is lower than $5 \%$, which is the level of significance adopted for this study

i.e $(0.0000<0.05)$. The coefficient showed that one unit change in net income will cause a positive 21.74 unit change in EPS. This positive effect of net income on EPS is statistically significant in this study.From the above regression analysis, net income has a significant effect on EPS. Therefore, from the test of hypothesis three, the null hypothesis is rejected; research question three is answered and research objective three is achieved. This shows that there is a strong relationship between net income and EPS in Nigerian quoted companies.

Test of Hypothesis Four (H04)- There is no significant influence of return on asset (ROA) on productivity(EPS) in Nigerian quoted companies.

Cross-sections included: 53

Total panel (balanced) observations: 265

Table 4.5 Regression on Return on Assets

\begin{tabular}{lcllc}
\hline \multicolumn{1}{c}{ Variable } & Coefficient & Std. Error & t-Statistic & Prob. \\
\hline \hline C & 160.4036 & 23.58327 & 6.801582 & 0.0000 \\
ROA & 1318.345 & 227.3661 & 5.798333 & 0.0000 \\
\hline \hline R-squared & 0.113346 & Mean dependent var & 254.9885 \\
Adjusted R-squared & 0.109974 & S.D. dependent var & 293.8847 \\
S.E. of regression & 277.2543 & Akaike info criterion & 14.09527 \\
Sum squared resid & 20216793 & Schwarz criterion & 14.12228 \\
Log likelihood & -1865.623 & Hannan-Quinn criter. & 14.10612 \\
F-statistic & 33.62067 & Durbin-Watson stat & 2.226131 \\
Prob(F-statistic) & 0.000000 & & & \\
\hline
\end{tabular}

Source: E-Views Regression analysis results

$\mathrm{EPS}=\beta 0+\beta 1$ ROAit $+\mathrm{e}_{\mathrm{it}}$

$\mathrm{EPS}=160.4+1318.34 \mathrm{ROA}$

The result of the regression estimate for model 4 indicates that return on asset have positive effect on EPS. This is indicated by the sign of coefficient $(\beta 1=1318.34)>0$. Thus, return on asset is consistent with pre-estimation expectation.The R-squared showed that about $11 \%$ variations in EPS can be attributed to return on asset and the remaining $89 \%$ variations in EPS for the sampled companies were caused by some other factors extraneous to this study.The probability of t-statistics showed $0 \%$ for the sampled companies. This shows that the regression result is statistically significant because this is lower than $5 \%$, which is the level of significance adopted for this study i.e $0.0000<0.05$. The coefficient showed that one unit change in return on asset will cause a positive 1318.34 unit change 
in EPS. This positive effect of return on asset on EPS is statistically significant in this study.From the above regression estimates, return on asset has significant effect on EPS. Therefore, from the test of hypothesis four, the null hypothesis is rejected; research question four is answered and research objective four is achieved. This shows that there is significant influence of return on asset on productivity in Nigerian quoted companies.

\section{Diagnostic Test}

The Breusch Pagan/cook Weisberg test for heteroskedasticity of H0 of constant variance revealed the p-value of chi ${ }^{2}$ statistics of 0.0005 indicating that the data set is homoscedastic; hence we accept the null hypothesis. Secondly, the result of the Wooldridge test for autocorrelation in panel data with $\mathrm{H} 0$ of no-first order serial correlation indicates a pvalue of chi $^{2}$ statistic of 0.0621 implying that there is no evidence of serial correlation. This position is confirmed by the Durbin Watson statistics of 2.392 indicating that the evidence of slight negative serial correlation is not statistically significant. On the basis of the above test, we used pooled OLS regression which satisfy the fundamental assumption of the normality, homoscedasticity and no-serial correlation. The results of all estimates and other inferential statistics are hereby presented below.

\section{Main Model}

Dependent Variable: EPS

Method: Panel Least Squares

Table 4.6 Multiple Regression

\begin{tabular}{|c|c|c|c|c|}
\hline Variable & Coefficient & Std. Error & t-Statistic & Prob. \\
\hline $\begin{array}{c}\text { LOGCOS0 } \\
\text { LOGOPC } \\
\text { LOGNI } \\
\text { ROA }\end{array}$ & $\begin{array}{r}-1293.409 \\
99.26220 \\
-18.20715 \\
2.888836 \\
1447.795\end{array}$ & $\begin{array}{l}141.1794 \\
13.77932 \\
12.19503 \\
3.854657 \\
208.9885\end{array}$ & $\begin{array}{r}-9.161457 \\
7.203708 \\
-1.492997 \\
0.749441 \\
6.927627\end{array}$ & $\begin{array}{l}0.0000 \\
0.0000 \\
0.1367 \\
0.4543 \\
0.0000\end{array}$ \\
\hline $\begin{array}{l}\text { R-squared } \\
\text { Adjusted R-squared } \\
\text { S.E. of regression } \\
\text { Sum squared resid } \\
\text { Log likelihood } \\
\text { F-statistic } \\
\text { Prob(F-statistic) }\end{array}$ & $\begin{array}{r}0.378436 \\
0.368873 \\
233.4723 \\
14172419 \\
-1818.557 \\
39.57486 \\
0.000000\end{array}$ & \multicolumn{2}{|c|}{$\begin{array}{l}\text { Mean dependent var } \\
\text { S.D. dependent var } \\
\text { Akaike info criterion } \\
\text { Schwarz criterion } \\
\text { Hannan-Quinn criter. } \\
\text { Durbin-Watson stat }\end{array}$} & $\begin{array}{l}254.9885 \\
293.8847 \\
13.76269 \\
13.83023 \\
13.78983 \\
2.391794\end{array}$ \\
\hline
\end{tabular}

Source: E-View Regression analysis results

$\mathrm{EPS}=\beta 0+\beta 1 \log \mathrm{COSit}+\beta 2 \log \mathrm{OC}$ it $+\beta 3 \log \mathrm{NI} i \mathrm{t}+\beta 4 \mathrm{ROA}+$ eit

$\mathrm{EPS}=-1293.4+99.26 \mathrm{COS}-18.2 \mathrm{OC}+2.89 \mathrm{NI}+1447.8 \mathrm{ROA}$

The results of the multiple regression estimate for the main model indicates that cost of sales, net income and return on asset (ROA) have positive effect on EPS while operating cost has negative effect. This is indicated by the sign of co-efficients $(\beta 1, \beta 3$, and $\beta 4=99.26,2.89$ and 1447.8) $>0$ and $(\beta 2=-18.2)<0$. The R-squared showed that about $38 \%$ variations in EPS can be attributed to the variations in cost of sales, operating cost, net income and return on asset. This means that about $62 \%$ systematic variations in EPS for the sampled companies were caused by other factors extraneous to this study. Also, the adjusted R-squared of 0.368 shows that after adjusting for the degree of freedom the entire variables taken together could still explain about $37 \%$ of the systematic variations in EPS. The probability of Fstatistics showed $0 \%$ for the sampled companies. This shows that the multiple regression result is statistically significant because this is lower than $5 \%$, which is the level of significance adopted for this study i.e $0.0000<0.05$. This means that cost of sales, operating cost, net income and return on asset taken together have significant impacts on EPS at 5\% level of significance. From the above regression estimates, the combined effects of the stated variables have significant effect on productivity. This shows that there is a significant impact between combined responsibility accounting variables and productivity in Nigerian quoted companies.

\section{Discussion of Findings}

The purpose of this study was to examine the relationship between responsibility accounting and productivity in Nigerian quoted companies. The descriptive statistics indicate that there are no much statistical differences in the mean and standard deviation scores and values of responsibility accounting and productivity indicators. The standard deviation scores are below one scale limit and very close to the mean. The overall results show that there is no much dispersion between the independent and the dependent variables. This means that volume and cost of sales in the Nigerian quoted companies add value to the shareholders wealth. When there is efficient management and control of cost within an organization, the value of the shareholder wealth will be increased. Cost increase as a result of good innovation, diversification, expansion, increase in the volume of output will in no doubt create additional wealth for the shareholders. This implies that if responsibility accounting is actively instituted in an organization, cost management, 
efficiency and control will be seriously enhanced and in effect the global out-turn will be productive. The combined proxies for responsibility accounting have significant effect on productivity (p-F-stat.=0.0000). The responsibility accounting variables of cost of sales, operating cost, net income and return on asset showed a significant joint effect as surrogated on the productivity using EPS of Nigerian quoted companies. Responsibility accounting specifically identifies revenue centre, cost centre, profit centre and investment centre which when properly managed engender high productivity.

\section{Conclusion:}

The study concludes that responsibility accounting has a significant positive effect on productivity in Nigerian quoted companies as all the independent variables if efficiently managed and controlled can create and add value in Nigerian quoted companies.

Recommendations: The following are recommended for implementation:

1 managers should strive to increase the value of the business and maximize the wealth of shareholders

2 Managers of the responsibility centres should be involved in setting the objectives, preparing the estimated budgets and performance level expected of them. This will spur the managers and employees to work harder and ultimately affects the company's performance positively.

3 Responsibility accounting reports should be arranged in accordance with the responsibility stage in the organization chart. At each level, the costs directly emerging at that level and the costs related to the managers in the bottom level should be shown.

4 Managers at all levels should ensure that all their actions are geared towards productivity of their companies. Production costs, operating and other associated costs should be reduced to the barest minimum in order to provide reasonable returns for the shareholders and in turn increase the wealth of shareholders.

5 Managers should institute good asset replacement policy for the company. Through this, obsolete and ageing assets can be identified and replaced as at when due and this will devoid the company of unnecessary delay in production, stock out, customer deflection, poor service rendering, and poor performance in other investment areas.

\section{REFERENCES}

[1].Adeniji, A. A. (2012). An insight into management accounting. Lagos: Value Analysis Publishers.

[2].Andor, P.(2014) Responsibility accounting in the hospitality industry.Journalof Education, Culture \& Scocity.2:5360

[3].Attu, O. S. K., Ogbeide, E., Agbo, I.S., \& Clement, E.O. (2014). Responsibility accounting: an overview. IOSR Journal of Business and Management, 16(1), 73-79.

[4].Beinabaj, M. H., Soleiman, M., \& Rashidi, M. (2013). The relationship between total asset turnover and productivity indicators of companies listed in Tehran Stock Exchange. Advances in Environmental Biology, 7(8), 1648-1653.

[5].Berle, A. A., \& Means, G. C. (1932). The modern corporation and private property. New York, Macmillan.

[6].Central Bank of Nigeria(2014) Annual Economic Report.

[7].Effiok, S. O., \& Bessong P. K, (2015). Cost information and business strategy: a synergistic approach of ensuring valid business decision and growth. European Journal of Business and Innovation Research, 4(2), 1-10.

[8].Elliot, B., \& Elliot, J. (2002). Financial accounting and reporting. London : Prentice Hall/ Financial Times.

[9].Enekwe, C. I, (2015). The relationship between financial ratio analysis and corporate profitability: a study of selected quoted oil and gas companies in Nigeria. European Journal of Accounting, Auditing and Finance Research, 3(2), 17-34.

[10]. Fowzia, R. (2011). Use of responsibility accounting and measure the satisfaction levels of Service Organisation in Bangladesh. International Review of Business Research Papers, 7(5), 53-67.

[11]. Freeman, A. B. (1983). Toward an epistemology for radical accounting: beyond objectivism and relativism. Critical Perspectives on Accounting, 6(1), 485-496.

[12]. Freeman, R. E. (1984). Strategic management: A stakeholder approach. Boston: Pitman. Friedman, M. (1970). The social responsibility of business is to increase its profits. New York :Times Magazine.

[13]. Gharaiba, F., Debi, M., \& Abo, N. M. (2011). The extent of applying the elements of responsibility accounting in the industrial shareholding companies and its effect on the company's profitability and operational efficiency. Derasat Administrative Sciences, 38(1), 219- 234.

[14]. Ikon, M. A., \& Nwankwo, C. N. (2015). Production planning and profitability of selected manufacturing firms in Nigeria. International Journal of Business and Management Review, 4(1), 11-32.

[15]. Innes, J., \& Mitchell, F. (1991). A review of activity-based cost practice in handbook of management accounting practice, Butterworth-Heinemann.

[16]. Jensen, M., \& Meckling, W. (1976). Theory of the firm: managerial behaviour, agency costs and capital structure. Journal of Financial Economics, 3, 11-25.

[17]. Jensen, M., \& Runback, R. (1983). The market for corporate control: the scientific evidence, Journal of Financial Economics, 11, 5-50.

[18]. Joshi,S.(2016). What is corporate sustainability and how do firms practice it?A managerial accounting research perspective.American Accounting Association journal of management accounting research.28(2),1-11

[19]. Kabajeh, M. A., Al Nu'aimat, S. M., Dahmash, F. N. (2012). The relationship between the ROA, ROE and ROI Ratios with Jordanian insurance public companies market share prices, International Journal of Humanities and 
Social Science, 2(11). 115-120.

[20]. Kajola, S. O., Adedeji, S. B., \& Okewale, J. A. (2003) Management accounting. Ijebu Ode: CESAP.

[21]. Karasioghu, F., \& Gokturk, I. E. (2012). The applicability of responsibility accounting system with the scope of increasing efficiency in hospital businesses in Turkey. Journal of Finance, 2, 199-203.

[22]. Khalid, A. C. (2012). The impact of asset quality on profitability of private banks in India.

[23]. Journal of African Macroeconomic Review of Accounting Studies, 2(1), 127-143.

[24]. Khan, K. I. (2012). Effect of dividends on stock prices. Proceedings of 2nd International Conference Business Management. Retrieved from http://www.umt.edu.pk/icobm2012/pdf/2C-32P.pdf, 28.11.2013.

[25]. Maran,L.,Bracci,E.\& Inglis,R.(2018).Performance management systems stability:unfolding the human factor-A case from the Italian public sector.The British Accounting Review.50(3),324- 339.

[26]. Meo,F.D.,Lara,J.M.G.\& Surroca,J.A.(2017).Managerial entrenchment and earnings management.Journal of Accounting and Public Policy 36(5),399-414.

[27]. Mohammad, E. N., Abdul-rahman, Z., Mahmoud, F., \& Atala, Q. (2014). An empirical assessment of measuring the extent of implementing responsibility accounting rudiments in Jordanian Industrial Companies listed at Amman Stock Exchange. Journal of Advances in Management \& Applied Economics, 4(3), 124-138.

[28]. Mojgan, S. (2012). Examining the role of responsibility accounting in organizational structure. American Academic \& Scholarly Research Journal, 4(5), 1-6

[29]. Muneer,M.F.J., Faroug,A.A.,Mohammed,A.R. and Ata, E.M.A.S.(2016).The availability of components accounting responsibility in industrial companies in AQABA city.European Scientific Journal 8(22) 14-27.

[30]. Nedles, B. E., Powers, M., \& Crosson, S. V. (2002). Financial and managerial accounting. New York : Houghton Mifflin Company Boston, New York :Times Magazine.

[31]. Okwo, I. M., Ugwunta, D. O., \& Nweze A. U. (2012). Investment in fixed assets and firm profitability: evidence from the Nigerian brewery industry. European Journal of Business and Management, 4(20), 10-17.

[32]. Oyadonghan, K. J., \& Ramond, L. (2014). The effect of quality cost management on firm's profitability. British Journal of Marketing Studies, 2(1), 12-26.

[33]. Oyerogba, E. O., Olaleye, M. O., \& Solomon, A. Z. (2014). Cost management practices and firm's performance of manufacturing organizations. International Journal of Economics and Finance, 6(6), 234239.

[34]. Pandey, I. M. (2002). Management accounting. New Delhi: VIKAS Publishing House PVT LTD

[35]. Pandey, I. M. (2010). Financial management. New Delhi: VIKAS Publishing House PVT LTD

[36]. Rayeni, M., \& Saljooghi, F. (2012). Equitable allocation of fixed costs and its effect on technical and cost efficiency: Case study in universities, 1263-1269.

[37]. Roslas, L. (1948). International comparisons of productivity. International Labour Review, 58, 95-102.

[38]. Ross, S. A. (1977). The determination of financial structure: the incentive signaling approach. Bell Journal of Economics:, 5, 23-40.

[39]. Said, A. (2011). Comparing the change in efficiency of the Western and Islamic Banking Systems. Journal of Money, Investment and Banking, 23, 9-15.

[40]. Sayeed, M. A., \& Hogue, M. S. (2009). Impact of assets and liability management on profitability: a study of public vs private Commercial Bank in Bangladesh. Available from www.wbicconpro.com $/ 30 \% 5 B / \% 5 D .2017$

[41]. Warrad, L., \& Omari, R. (2015). The impact of turnover ratios on Jordanian services sectors performance. Journal of Modern Accounting and Auditing, 11(2), 77-85.

[42]. Yeshmin,F.and Fowzia,R.(2010).Management accounting practices: A comparative analysis of manufacturing and service industry ASA University Review 4(1), 131-141

[43]. Zerbe, R. O. (2001). Economic efficiency in law and economics. UK: Edward Elgar Publishing. 